\title{
PENGARUH MODEL PEMBELAJARAN BERBASIS MASALAH TERHADAP MINAT DAN HASIL BELAJAR KONSTRUKSI BANGUNAN PADA SISWA KELAS X PROGRAM KEAHLIAN TEKNIK GAMBAR BANGUNAN SMK NEGERI 1 PERCUT SEI TUAN T.A 2016/2017
}

\author{
Herianto', Kinanti Wijaya ${ }^{2}$ \\ ${ }^{1}$ Alumni Program Studi S1 Pendidikan Teknik Bangunan, Fakultas Teknik, UNIMED, Medan \\ 2Dosen Pengajar Jurusan Pendidikan Teknik Bangunan, Fakultas Teknik, UNIMED, Medan \\ Surel : heryantonasution@gmail.com ${ }^{1}$,kinanti.w@gmail.com ${ }^{2}$
}

Diterima : 22 Mei 2018; Disetujui : 31 Mei 2018

\begin{abstract}
ABSTRAK
Penelitian ini bertujuan untuk mengetahui pengaruh pembelajaran berbasis masalah terhadap hasil belajar Konstruksi Bangunan siswa SMK Negeri 1 percut sei tuan Tahun Ajaran 2017/2018. Jenis penelitian ini adalah penelitian eksperimen. Populasi dalam penelitian ini adalah seluruh siswa kelas X jurusan teknik gambar bangunan yang terdiri dari kelas TGB 1 dan TGB 2 yang berjumlah 60 orang. Pengambilan sampel dalam penelitian ini dilakukan dengan teknik total sampling, dimana keseluruhan populasi dijadikan sampel. Instrumen penelitian yang digunakan untuk mengumpulkan data adalah objektif tes berbentuk pilihan berganda yang berjumlah 25 soal dengan 4 opsi jawaban. Hasil analisis data setelah diberikan perlakuan dengan masing-masing model pembelajaran menunjukkan bahwa kelas yang diajarkan dengan model pembelajaran berbasis masalah memperoleh nilai rata-rata sebesar 84,80, dan standar deviasi sebesar 5,82. Sedangkan kelas yang diajarkan dengan model konvensional memperoleh nilai rata-rata sebesar 72,07 dan standar deviasi sebesar 3,74. Pengujian hipotesis dilakukan dengan menggunakan statistik uji-t Dari perhitungan hipotesis diperoleh $t_{\text {hitung }}$ sebesar 3,89 dan $t_{\text {tabel }}$ sebesar 1,68. Hasil pengujian hipotesis menunjukkan bahwa $t_{\text {hitung }}>t_{\text {tabel }}(3,89>1,68)$ maka hipotesis alternatif $(\mathrm{Ha})$ diterima dan hipotesis nol $\left(\mathrm{H}_{0}\right)$ ditolak. dan minat belajar siswa dengan model konvensional memiliki rata-rata 61,63 dan pembelajaran berbasis masalah 83,61 mengalami peningkatan 26,28\% Dari hasil tersebut dapat disimpulkan bahwa ada pengaruh yang positif dan signifikan model pembelajaran berbasis masalah terhadap minat dan hasil belajar Konstruksi Bangunan
\end{abstract}

Kata Kunci : Berbasis Masalah, Hasil Belajar, Minat Belajar, Model Konvensional, Pembelajaran

\begin{abstract}
This study aims to determine the effect of problem-based learning on learning outcomes of Building Construction students SMK Negeri 1 Percut Sei Tuan Year of Teaching 2017/2018. This type of research is experimental research. Population in this research is all class $X$ student majoring in building drawing techniques consisting of TGB 1 and TGB 2 class of 60 people. Sampling in this study was done by total sampling technique, where the entire population was sampled. The research instrument used to collect the data is the objective of multiple choice test consisting of 25 questions with 4 answer options. The results of the data analysis after the handling given to each study model shows that the class is taught by a problem-based learning model scored an average of 84.80, and a standard deviation about 5.82. While the classes taught by the conventional model obtain an average value about 72.07 and standard deviation about 3.74. Hypothesis testing is done by using t-test statistic. From the calculation of the hypothesis obtained $t$-count of 3.89 and $t$-table of 1.68. The result of hypothesis testing shows that $t$-hitung $>$ t-table $(3.89>1.68)$ then the alternative hypothesis $(\mathrm{Ha})$ is accepted and the null hypothesis (HO) is rejected. And students' learning interest with conventional model has an average of 61.63 and problem based learning 83,61 experienced an increase of 26,28\%. From these results it can be concluded that there is a positive and significant effect of problem-based learning model on Building Construction interest and learning outcomes.
\end{abstract}

Keywords: Problem Based, Learning Outcomes, Interest In Learning, Conventional Model, Learning 


\section{Pendahuluan}

Dalam Undang-Undang No. 20 Tahun 2003 menjelaskan pendidikan nasional mempunyai visi terwujudnnya sistem pendidikan sebagai pranata sosial yang kuat dan berwibawa untuk memberdayakan warga Negara Indonesia berkembang menjadi manusia yang berkualitas sehingga mampu dan proaktif menjawab tantangan zaman yang selalu berubah. Dengan pendidikan manusia dapat mengembangkan potensi yang dimilikinya, yaitu mengubah tingkah laku kearah yang lebih baik.

Berdasarkan hasil observasi awal peneliti di SMK Negeri 1 Percut Sei Tuan Medan, berupa wawancara terhadap guru mata pelajaran Konstruksi Bangunan dan mengumpulkan dokumen-dokumen seperti nilai ulangan harian dan absensi siswa. Selanjutnya, mengamati kondisi kelas saat proses pembelajaran dan bertanya kepada siswa tentang metode mengajar yang dilakukan dan diterapkan oleh guru di kelas.

Hasil dari observasi proses pembelajaran yang dilakukan oleh guru bidang studi, siswa hanya bisa mendengar ceramah guru dan mencatat setiap catatan yang diberikan oleh guru. dan kebnyakan siswa cenderung kurang aktif dalam proses belajar mengajar. berdasakan nilai harian siswa dapat disimpulkan bahwa pelajaran konstruksi bangunan masih rendah.

Dari hasil belajar konstruksi bangunan terlihat jelas bahwa masih banyak hasil belajar siswa yang rendah. Berdasarkan kriteria ketuntasan minimal (KKM) pada mata pelajaran konstruksi bangunan yang ditetapkan oleh sekolah adalah nilai 75, maka pada tahun ajaran 2015/2016 semester ganjil terdapat $56 \%$ siswa berada dalam kriteria cukup, $44 \%$ Dari penjelasan di atas dapat disimpulkan bahwa hasil belajar siswa pada mata pelajaran konstruksi bangunan masih rendah.

Diduga penyebab utamanya yaitu pembelajaran didominasi oleh guru yang masih menggunakan model konvensional dan guru masih mengajarkan dengan materi pelajaran yang ada dibuku, dimana guru menerangkan dan siswa hanya menyimak dan mencatat materi pelajaran. Dengan pembelajaran yang berpusat pada guru, keinginan untuk belajar siswa menjadi tidak ada dan hasil belajarnya rendah. Untuk memperbaiki masalah di atas perlu dilakukan perubahan model pembelajaran dalam menyampaikan isi pembelajaran, dan memberdayakan sumber- sumber yang ada di lingkungan sekolah maupun yang dimiliki siswa. Sudirman (2001) Menyatakan Model pembelajaran yang kurang efektif dan efisien, misalnya pembelajaran yang monoton, guru yang bersifat otoriter dan kurang bersahabat dengan siswa sehingga siswa merasa terbebani dan bosan serta kurangnya minat siswa untuk belajar. Hal ini guru harus meningkatkan kualitas profesionalismenya dengan cara memberikan kesempatan belajar kepada siswa dengan melibatkan siswa secara efektif dalam proses pembelajaran.Untuk meningkatkan kualitas proses dan hasil belajar, para ahli pembelajaran telah menyarankan penggunaan paradigma pembelajaran konstruktivistik untuk kegiatan belajar mengajar di kelas. Dengan perubahan paradigma belajar tersebut terjadi perubahan fokus pembelajaran dari belajar berpusat pada guru menjadi belajar berpusat pada siswa. Dengan kata lain, ketika mengajar di kelas, guru harus berupaya menciptakan kondisi lingkungan belajar yang mendorong siswa untuk belajar atau memberi kesempatan kepada siswa untuk berperan aktif. Untuk mencapai tujuan tersebut, maka dilakukan pemilihan model pembelajaran yang lebih baik yang dapat meningkatkan hasil belajar siswa. Salah satu alternatif yang dapat digunakan yaitu melalui model pembelajaran berbasis masalah, yang dapat memberikan ruang seluasluasnya hanya kepada siswa untuk berpikir dan terlibat secara aktif serta kreatif dalam suatu pembelajaran. Slameto (1995) Dapat disimpulkan bahwa, pembelajaran berbasis masalah merupakan suatu model pembelajaran dimana siswa dihadapkan dengan masalah aktual sehingga siswa mampu untuk belajar tentang cara berfikir kritis dan terampil memecahkan masalah, serta untuk memperoleh pengetahuan dan konsep yang penting dari materi pembelajaran.

Berdasarkan permasalahan diatas, penulis merasa tertarik untuk mengadakan penelitian untuk melihat "Pengaruh Model Pembelajaran Berbasis Masalah Terhadap Minat dan Hasil Belajar Konstruksi Bangunan Pada Siswa Kelas X Program Keahlian Teknik Gambar Bangunan SMK Negeri 1 Percut Sei Tuan".

\section{Kajian Pustaka}

2.1 Hakikat Pembelajaran Berbasis Masalah

Model pembelajaran diperlukan untuk dapat mencapai aktivitas dan hasil belajar yang semaksimal mungkin. Banyak model 


\section{Pengaruh Model Pembelajaran Berbasis Masalah Terhadap Minat Dan Hasil Belajar Konstruksi Bangunan Pada Siswa Kelas X Program Keahlian Teknik Gambar Bangunan Smk Negeri 1 Percut Sei Tuan T.A 2016/2017}

pembelajaran yang dapat digunakan untuk menentukan keberhasilan suatu proses pembelajaran di kelas salah satunya dalam bentuk model pembelajaran berbasis masalah. Model pembelajaran berbasis masalah dapat diartikan sebagai rangkaian aktivitas pembelajaran yang menekankan kepada proses penyelesaian masalah yang dihadapi secara ilmiah (Sanjaya, 2006:214).

\subsection{Hakikat Minat Belajar}

Minat adalah kecenderungan subyek untuk merasa tertarik pada bidang studi atau pokok bahasan tertentu dan merasa senang mempelajari materi itu. Besar kecilnya minat akan mempengaruhi keberhasilan bagi setiap kreativitas manusia. Sardiman (2001) mengatakan minat diartikan sebagai suatu kondisi yang terjadi apabila seseorang melihat ciri-ciri atau arti sementara situasi yang dihubungkan dengan keinginan-keinginan atau kebutuhan-kebutuhannya sendiri. Syah (1995) mengemukakan bahwa minat (interest) berarti kecenderungan yang tinggi atau keinginan yang besar terhadap sesuatu. Sedangkan menurutWitherington (1982)minat adalah kesadaran seseorang, bahwa suatu obyek, seseorang, suatu soal atau suatu situasi berkaitan dirinya. Menurut Singer (1991) Minat adalah suatu landasan yang paling meyakinkan dalam keberhasilan suatu proses belajar. Seorang murid memiliki rasa ingin belajar, maka murid akan cepat dapat mengerti dan mengingatnya.

\subsection{Hakikat Belajar}

Menurut Kurjono (2010) mengemukakan bahwa belajar adalah suatu aktivitas mental atau psikis yang berlangsung dalam interaksi aktif dengan lingkungan, yang menghasilkan perubahan dalam pengetahuan, pemahaman, keteramplan nilai sikap. Sedangkan menurut Slameto (2003:2) bahwa, “ belajar adalah suatu proses usaha yang dilakukan seseorang untuk memperoleh suatu perubahan tingkah laku yang baru secara keseluruhan sebagai hasil pengalamannya sendiri dalam berinteraksi dalam lingkungannya. Dari beberapa penjelasan di atas, belajar dapat diartikan sebagai proses membangun pemahaman dari seseorang yang melibatkan kegiatan (proses) berfikir dan terjadi melalui pengalamanpengalaman terhadap lingkungan di mana ia berada, sehingga terjadi perubahan tingkah laku pada indivindu belajar. Belajar adalah proses untuk memperoleh pengetahuan, keterampilan dan sikap yang menghasilkan suatu perubahan tingkah laku. Sedangkan hasil dari proses belajar tersebut dinamakan hasil belajar.

\subsection{Hipotesis Penelitian}

Model pembelajaran pada dasarnya adalah tindakan nyata dari guru atau merupakam praktek guru melaksanakan pengajaran melalui cara tertentu yang dinilai lebih efektif dan efisien.

Berdasarkan deskripsi diatas, maka hipotesis dari penelitian ini "Diduga model Pembelajaran berbasis masalah Memberi Pengaruh Yang Berbeda Secara Signifikan Terhadap Minat dan Hasil Belajar Konstruksi Bangunan Siswa SMK Negeri 1 Percut Sei Tuan T.A 2017/2018".

\section{Metodologi}

Penelitian ini dilaksanakan di SMK Negeri 1 Percut Sei Tuan Medan yang beralamat di Jalan Kolam No 3, Mesan Estate. Waktu dilakukannya penelitian yaitu pada semester genap tahun pelajaran 2017/2018.

Populasi dalam penelitian ini adalah seluruh siswa kelas $\mathrm{X}$ program keahlian teknik gambar bangunan SMK Negeri 1 Percut Sei Tuan Medan Tahun Pelajaran 2017/2018 yang berjumlah 60 siswa. Kelas TGB 1 sebagai kelas eksperimen dan Kelas TGB 2 sebagai kelas kontrol. Penelitian ini termasukpenelitian kuasi eksperimen/eksperimen semu. Pada pelaksanaan penelitian ini dilibatkan dua perlakuan yang berbeda antara kelas eksperimen dan kelas kontrol.

\subsection{Teknik Pengumpulan Data}

Pengumpulan data dalam penelitian ini dengan menggunakan tes dan angket belajar. Tes yang diberikan adalah tes objektif yaitu 30 soal pillihan berganda denngan 4 alternatif jawaban. dan angket yang diberikan sebanyak 30 soal dan diberi 4 opsi jawaban.

\subsection{Hasil Uji Coba Instrumen}

Dari hasil uji coba instrumen yang dilakukan di kelas X TGB (Teknik Gambar Bangunan) SMK Negeri 1 Percut Sei Tuan, dari 30 butir soal tes pilihan berganda diperoleh 25 butir soal yang valid dan 5 butit soal tidak valid yaitu soal no. 8, 10, 17, 22, dan 26. Diperoleh nilai reliabilitas sebesar $r_{11}=0,843$ yang tergolong sangat tinggi. Dari 25 butir soal yang 
duujikan tingkat kesukaran, didapat 6 butir soal yang sukar, 9 butir soal yang sedang, dan 10 butir soal yang mudah. Dari 25 butir soal yang duujikan tigka daya bedanya, terdapat 3 butir soal berkategori jelek, 13 butir soal berkategori cukup dan 9 butir soal berkategori baik. Dan dari 30 butir angket yang diujikan validitasnya, didapat 22 soal yang valid dan 8 soal yang tidak valid, dimana soal yang tidak valid terdapat pada soal nomor $5,6,7,8,13,17,18$, dan 28 .

\subsection{Teknik Analisis Data}

Teknik analisis data dilakukan dengan cara melakukan Uji Normalitas, Uji Homogenitas, dan Uji Hipotesis. Pada tahapan Uji Normalitas data dilakukan untuk mengetahui normal tidaknya data peneliti dari tiap variabel penelitian. Uji Normalitas yang yang digunakan dalam penelitian ini adalah uji liliefors. Tahapan Uji Homogenitas yang digunakan adalah cara varians terbesar dibandingkan dengan varians terkecil, dengan menggunakan uji f dan Uji Hipotesis yang digunakan dalam penelitian ini adalah uji $t$ dengan cara mendistribusikan data posttest kelas eksperimen dan kelas kontrol dengan $\alpha=$ 0,05 , jika $t_{\text {hitung }}>t_{\text {tabel }}$, maka Ha diterima dan Ho ditolak.

\section{Hasil dan Pembahasan}

Dalam penelitian ini terdapat jumlah siswa 60 orang yang masing-masing pada kelas pada kelas yang diberi perlakuan model pembelajaran berbasis masalah sebanyak 30 orang dan kelas yang diberi perlakuan model konvensional sebannyak 30 orang. Sebelum perlakuan setiap siswa diberikan pretest dan setelah diberikan perlakuan siswa diberikan posttest.

\subsection{Hasil Belajar Tidak Menggunakan Model Konvensional}

Hasil belajar sebelum diajarkan dengan model Konvensional diperoleh skor tertinggi 76, skor terendah 32, nilai rata-rata sebesar 53,73 , median sebesar 52, modus sebesar 52, standar deviasi sebesar 10,44 dan varians sebesar 108,9.

Hasil belajar sesudah diajarkan dengan model konvensional diperoleh skor tertinggi 96, skor terendah 72 , nilai rata-rata sebesar 84,80 , median sebesar 84 , modus sebesar 88 , standar deviasi sebesar 5,82 dan varians sebesar 33,86.
Peningkatan hasil belajar dengan penggunaan model pembelajaran berbasis masalah sebesar $36,63 \%$.

\subsection{Hasil Belajar Dengan Model Konvensional}

Hasil belajar sebelum diajarkan dengan model konvensional diperoleh skor tertinggi 76, skor terendah 32 , nilai rata-rata sebesar 53,07, median sebesar 52, modus sebesar 44 dan 52, standar deviasi sebesar 11,67 dan varians sebesar 134,50.

Hasil belajar sesudah diajarkan dengan model konvensional diperoleh skor tertinggi 83, skor terendah 68 , nilai rata-rata sebesar 72,60 , median sebesar 72 , modus sebesar 70 , standar deviasi sebesar 3,74 dan varians sebesar 37,44.

Peningkatan hasil belajar dengan penggunaan model konvensional sebesar $26,73 \%$.

\subsection{Uji Normalitas}

Uji normalitas nilai hasil belajar konstruksi bangunan siswa sebelum diajarkan dengan model pembelajaran berbasis masalah diperoleh L Litung 0,10 dan $\mathrm{L}_{\text {tabel }}$ 0,16. Uji normalitas nilai hasil belajar konstruksi bangunan siswa sesudah diajar dengan model pembelajaran berbasis masalah diperoleh $\mathrm{L}_{\text {hitung }}$ 0,14 dan $\mathrm{L}_{\text {tabel }} 0,16$. Nilai hasil belajar konstruksi bangunan siswa sebelum diajarkan dengan model konvensional diperoleh Lhitung 0,13 dan $L_{\text {tabel }}$ 0,16. uji normalitas nilai hasil belajar konstruksi bangunan sesudah diajarkan dengan model konvensional diperoleh $\mathrm{L}_{\text {hitung }}$ 0,11 dan $\mathrm{L}_{\text {tabel }}$ 0,16. Hal ini menunjukkan bahwa $\mathrm{L}_{\text {hitung }}<$ $\mathrm{L}_{\text {tabel }}$ yang berarti data berdistribusi normal.

\subsection{Uji Homogenitas}

Uji homogenitas data hasil belajar konstruksi bangunan siswa sebelum diajarkan dengan model pembelajaran berbasis masalah dan model konvensional diperoleh $\mathrm{F}_{\text {hitung }} 1,23$ dan $\mathrm{F}_{\text {tabel }}=1,86$.

Uji homogenitas data hasil belajar konstruksi bangunan siswa sesudah diajarkan model pembelajaran berbasis masalah dan model konvensional diperoleh $F_{\text {hitung }}$ 1,10 dan $\mathrm{F}_{\text {tabel }}=1,86$.

Dari data diatas diketahui bahwa nilai $\mathrm{F}_{\text {hitung }}<$ $F_{\text {tabel, }}$ sehingga dapat disimpulkan bahwa data hasil belajar konstruksi bangunan bersifat homogen.

\subsection{Pembahasan Penelitian}

Penelitian yang dilakukan di SMK Negeri 1 percut Sei Tuan ini bertujuan untuk melihat 


\section{Pengaruh Model Pembelajaran Berbasis Masalah Terhadap Minat Dan Hasil Belajar Konstruksi Bangunan Pada Siswa Kelas X Program Keahlian Teknik Gambar Bangunan Smk Negeri 1 Percut Sei Tuan T.A 2016/2017}

pengaruh model pembelajaran berbasis masalah dan model konvensional terhadap hasil belajar konstruksi bangunan. Penelitian ini termasuk penelitian kuasi eksperimen yang melibatkan dua kelas yaitu kelas TGB 1 yang diberi perlakuan dengan model pembelajaran berbasis masalah dan kelas TGB 2 yang diberi perlakuan dengan model konvensional.

Dalam penelitian ini, berdasarkan uji hipotesis yang dilakukan didapat nilai $t_{\text {hitung }}=$ 3,89 dan $t_{\text {tabel }}=1,68$ (dengan taraf signifikan $\alpha=$ 0,05 dan $d k=58$ ), sehinngga $t_{\text {hitung }}>t_{\text {tabel yaitu }}$ $3,89>1,68$ yang berarti $\mathrm{Ha}$ diterima dan $\mathrm{Ho}$ ditolak. Sehingga dapat disimpulkan bahwa ada pengaruh positif dan signifikan model pembelajaran berbasis masalah terhadap minat dan hasil belajar konstruksi bangunan siswa.

Hasil belajar konstruksi bangunan siswa yang diajarkan dengan model pembelajaran berbasis masalah lebih tinggi dibandingkan dengan hasil belajar konstruksi bangunan siswa yang diajarkan dengan model konvensional.

\section{Simpulan Dan Saran}

\subsection{Simpulan}

1) Model pembelajaran berbasis masalah memberikan pengaruh yang positif dan signifikan terhadap hasil belajar konstruksi bangunan. Hasil belajar siswa yang diajarkan dengan menggunakan model pembelajaran berbasis masalah lebih tinggi dibandingkan hasil belajar siswa yang diajarkan dengan menggunakan model konvensional. Hal tersebut diketahui dengan membandingkan nilai rata-rata hasil belajar konstruksi bangunan siswa sebelum dan sesudah pembelajaran diperoleh peningkatan hasil belajar siswa dengan menggunakan model pembelajaran berbasis masalah sebesar $36,63 \%$ dan pada model konvensional sebesar $26,73 \%$.

2) Dengan membandingkan rata-rata minat belajar konstruksi bangunan dengan model pembelajaran berbasis masalah sebesar 83,61 dengan model konvensional sebesar 61,63. Dari data tersebut dapat dilihat bahwa minat belajar kostruksi bangunan dengan model pembelajaran berbasis masalah mengalami peningkatan $26,28 \%$ dari model konvensional

\subsection{Saran}

1) Disarankan kepada sekolah untuk terus memantau dan membiasakan para guru bidang studi untuk memakai model pembelajaran yang beragam sesuai dengan materi guna meningkatkan hasil belajar siswa.

2) Disarankan kepada guru bidang studi Konstruksi Bangunan di kelas X SMK Negeri 1 Percut Sei Tuan, untuk menerapkan model pembelajaran berbasis masalah pada proses belajar mengajar yang selanjutnya sesuai dengan materi yang diajarkan.

\section{Daftar Pustaka}

Abidin,Yunus. 2014. Desain Sistem Pembelajaran Dalam Konteks Kurikulum 2013. Bandung: Refika Aditama.

Arikunto, Suharsimi. 2012. Dasar Evaluasi Pendidikan (Edisi Kedua). Jakarta: Bumi Aksara.

Dakir. (1993). Dasar-Dasar Psikologi. Yogyakarta: Pustaka Pelajar.

Djamarah, Syaiful Bahri. 2011. Psikologi Belajar. Jakarta: Rineka Cipta.

Hamzah, B. Uno. (2007). Model Pembelajaran (Menciptakan Proses Belajar Mengajar Yang Kreatif Dan Efektif). Jakarta. Bumi Aksara.

Hurlock. (1990). Psikologi Perkembangan. Jakarta : Erlangga Sepanjang Rentang Kehidupan, Edisi 5. Jakarta: Erlangga.

Jihad,A. Dan Abdul H. 2012. Evaluasi Pembelajaran. Yogyakarta: Multi Pressindo.

Kadir. 2015. Statistika Terapan. Depok: Raja Grafindo Persada

Kingsley, Howard. (1957). The Nature And Conditions Of Learning, Newjersey : Prentice Hall Ings Engliwood Clifts.

Kurjono (2010). Proses Belajar Mengajar Dengan Aspek-Aspeknya. Upi. Prodi Pendidikan Akutansi.

Loekmono. (1994). Belajar Bagaimana Belajar. Jakarta: BPK Gunung Mulia.

Majid, Abdul. 2011. Perencanaan Pembelajaran Mengembangkan Standar Kompetensi 
Guru. Bandung: Remaja

Rosdakarya.

Nurdin, N. N. (2014). Penerapan Model

Pembelajaran Berbasis Masalah Untuk

Meningkatkan Hasil Belajar Ilmu

Statika Dan Tegangan Siswa Kelas X

Program Keahlian Teknik Konstruksi

Batu dan Beton SMK Negeri 2 Binjai.

Skiripsi. Fakultas Teknik

Universitas Negeri Medan. Medan.

Purwanto, Ngalim. 2009. Prinsip-Prinsip Dan

Teknik Evalaluasi Pengajaran.

Bandung: Remaja Rosdakarya.

Rusman. (2011). Model-Model Pembelajaran. Jakarta: Rajawali

Safari. (2003). Indikator Minat Belajar. Jakarta Rineka Cipta

Sagala,Syaiful. 2013. Human Capital, Keepemimpinan Visioner, Dan Beberapa Kebijakan Pendidikan. Bandung: Alfabeta

Sanjaya, Wina. 2014. Strategi Pembelajaran Berorientasi Standart Pendidikan. Jakarta: Kencana Prenadamedia Group.

Singer, Kurt. (1987).Membina Hasrat Belajar Di Sekolah.Bandung: Remaja Karya.

Sardiman,A.M. (2001). Interaksi Dan Motivasi Belajar Mengajar. Jakarta: Raja GrafindoPersada.

Slameto, 2003. Belajar dan Faktor-Faktor Yang Mempengaruhinya, Jakarta: Rineka Cipta.

Sudjana,Nana. 2010. Penilaian Hasil Proses Belajar Mengajar.Bandung: Remaja Rosdakarya Offset.

Sudjana. 2009. Metoda Statistika. Bandung: Tarsito.

Suryabrata, Sumadi. (1989). Psikologi Kepribadian. Jakarta: PT. Raja Grafindo Persada.

Syah, Muhibbin. (1995). Psikologi Pendidikan Suatu Pendekatan Baru. Bandung: Remaja Rosdakarya.

Trianto. 2013. Mendesain Model Pembelajaran Inovatif Progresif. Jakarta: Kencana Media Group.

Whittaker, James O.(1999). Psikologi Belajar.Jakarta. Rineka Cipta

Winkel, W.S.(1991). Psikologi Pengajaran. Jakarta : PT. Grasindo

Witherington,H.C.,Dkk. （1982).Teknik-Teknik Belajar Dan Mengajar, Jemmars,

Yamin.(2013). Teori Dan Model Pembelajaran. Malang: Madani 